\title{
Optimization of chloroplast microsatellite PCR conditions and primer screening for endangered Rheum officinale, Rheum palmatum, and Rheum tanguticum
}

\author{
Y. Zhou ${ }^{1}$, Z.J. Guo ${ }^{1}$, L. Han ${ }^{2}$, Y. Li ${ }^{1}$ and X.M. Wang ${ }^{1}$ \\ ${ }^{1}$ School of Pharmacy, Xi' an Jiaotong University, Xi'an, China \\ ${ }^{2}$ College of Life Sciences, Shaanxi Normal University, Xi'an, China \\ Corresponding author: X.M. Wang \\ E-mail: xumeiwang@hotmail.com
}

Genet. Mol. Res. 13 (3): 5787-5794 (2014)

Received June 11, 2013

Accepted December 2, 2013

Published July 29, 2014

DOI http://dx.doi.org/10.4238/2014.July.29.6

\begin{abstract}
Chloroplast microsatellite primers were developed in order to provide more population genetic information of endangered Rheum officinale, $R$. palmatum, and $R$. tanguticum for conservation. The dried roots and rhizomes of these plants are important in traditional Chinese medicine. The results showed that the optimum concentrations of $\mathrm{Mg}^{2+}$, Taq DNA polymerase, dNTPs, template DNA, and primers in a $25-\mu \mathrm{L}$ reaction system were $2.0 \mathrm{mM}, 1.0 \mathrm{U}, 0.10 \mathrm{mM}, 20 \mathrm{ng}$, and 0.8 $\mu \mathrm{M}$, respectively. Fourteen of 53 primer combinations were chosen for their high clarity and repetition in three species, and their annealing temperatures ranged from 56 to $58^{\circ} \mathrm{C}$. These primers and the optimized polymerase chain reaction system may provide a tool for understanding the demography and genetic variation of these endangered plants.
\end{abstract}

Key words: Rhubarb; Chloroplast simple sequence repeat; Polymerase chain reaction optimization; Rheum 


\section{INTRODUCTION}

Rheum officinale Baill., R. palmatum L., and R. tanguticum Maxim. ex Balf. (Polygonaceae) are endemic species of China (Bao and Grabovskaya-Borodina, 2003). Their dried roots and rhizomes are important in traditional Chinese medicine (named rhubarb; Chinese Pharmacopoeia Committee, 2010). Bitter in flavor and cold in property, rhubarb is widely used as a purgative and anti-inflammatory agent (Chinese Pharmacopoeia Committee, 2010). The young stem and petioles of three source plants of rhubarb are also taken as vegetables and used in health foods (Su et al., 1998). Recent studies have revealed that rhubarb has anti-cancer properties and immunity function because of its rhein and polysaccharide content (Huang et al., 2007; Gao et al., 2008). These medicinal properties of rhubarb have attracted great interest in pharmaceutical and genetic variation research.

In our previous study, the distribution regions of the three species were found to be overlapping and vicarious (Wang et al., 2010), and no significant genetic difference was found at the species level by inter-simple sequence repeats (ISSRs) (Wang et al., 2012a,b). Although Chen et al. (2009) used simple sequence repeat (SSR) markers to detect the genetic diversity of rhubarb, only one species, $R$. tanguticum, was employed. The chloroplast chromosome is non-recombinant, uniparentally inherited in angiosperms, and effectively haploid. Chloroplast microsatellites (cpSSRs) are usually mononucleotide repeats that evolve faster than the other gene regions in the chloroplast genome (Jakob et al., 2007) and display high polymorphism. Furthermore, the short length and the limited number of alleles of most cpSSRs also permit the confirmation of allele size by sequencing (Weising and Gardner, 1999). This is more difficult for many nuclear SSRs, where the high heterozygosity and long size make distinct sequences difficult to obtain (Siragusa and Carimi, 2009). Therefore, they would be useful markers to gain more insights in genetic relationship studies of closely related species and populations, phylogeographic studies within a species, and marker-assisted selection (Provan et al., 2001; Cubas et al., 2005; Chen et al., 2007; Siragusa and Carimi, 2009; Melotto-Passarin et al., 2011).

In this study, we aimed to develop an efficient protocol of cpSSR-polymerase chain reaction (PCR) conditions and screen 53 primers and select those with high clarity and repetition for further investigation.

\section{MATERIAL AND METHODS}

\section{Plant materials}

The materials of $R$. officinale (voucher: Nanchuan, Chongqing, altitude of 1832 $\mathrm{m}, 29^{\circ} 00.008^{\prime} \mathrm{N}, 107^{\circ} 11.769^{\prime} \mathrm{E}, \mathrm{Xu}-\mathrm{mei}$ Wang and Xiao-qi Hou 09072609, SANU), $R$. palmatum (voucher: Dari, Qinghai, altitude of $3947 \mathrm{~m}, 33^{\circ} 49.151^{\prime} \mathrm{N}, 99^{\circ} 42.669^{\prime} \mathrm{E}$, Xiaoqi Hou 10081435, SANU) and R. tanguticum (voucher: Maqin, Qinghai, altitude of 3373 $\mathrm{m}, 34^{\circ} 36.955^{\prime} \mathrm{N}, 100^{\circ} 33.970 ' \mathrm{E}$, Xiao-qi Hou 10081332, SANU) were collected in 2009 and 2010. Chongqing and Qinghai are both main distribution regions and cultivated drug-producing areas (Wang et al., 2010). Fresh leaf samples from five wild individuals of each species were collected and preserved in zip-lock bags with silica gel until use. 


\section{DNA isolation}

The dried leaf tissue of $R$. officinale, R. palmatum, and $R$. tanguticum were sampled for DNA isolation by the improved $2 \mathrm{X}$ cetyltrimethylammonium bromide procedure (Doyle and Doyle, 1987). The quality and quantity of DNA were determined by an ultraviolet spectrophotometer (ND-2000, NanoDrop, USA). The DNA concentration and purity were also determined by electrophoresis on 1.0\% agarose gels based on the intensities of bands when compared with $1 \mathrm{~kb}$ plus DNA ladder as a marker. The DNA sample was diluted to the template concentration $20 \mathrm{ng} / \mu \mathrm{L}$ and stored at $-20^{\circ} \mathrm{C}$ until use.

\section{Optimization of the cpSSR-PCR system and primer screening}

A total of $53 \mathrm{cpSSR}$ primers were synthesized by Beijing Dingguo Biotech. Co. Ltd. (China) according to primer characteristics reported in other species (Vendramin et al., 1996; Weising and Gardner, 1999; Cheng et al., 2003; Chung and Staub, 2003; Sebastiani et al., 2004; Hu et al., 2009).

The PCR was carried out in Applied Biosystems Veriti Thermal Cycler (USA), in a total volume of $25 \mu \mathrm{L}$ containing $10 \mathrm{mM}$ Tris- $\mathrm{HCl}, \mathrm{pH} 8.3,50 \mathrm{mM} \mathrm{KCl}, 0.1 \%$ Triton X-100, $2.0 \mathrm{mM}$ $\mathrm{MgCl}_{2}, 0.2 \mathrm{mM}$ dNTPs, $0.4 \mu \mathrm{M}$ primer, $1 \mathrm{U}$ Taq Plus DNA polymerase (Tiangen, China) and 20 ng template DNA. The thermocycler was programmed for an initial denaturation of $5 \mathrm{~min}$ at $94^{\circ} \mathrm{C}$; 35 cycles of 30 seconds at $94^{\circ} \mathrm{C}, 30$ seconds at different annealing temperature for each primer, and extension at $72^{\circ} \mathrm{C}$ for 50 seconds; and a final extension at $72^{\circ} \mathrm{C}$ for $8 \mathrm{~min}$. Reactions without DNA were used as negative controls. Six factors including Taq DNA polymerase, dNTP, primer, $\mathrm{Mg}^{2+}$, and DNA template concentrations and annealing temperatures were estimated as described in Table 1. Eight microliters PCR product was electrophoresed on $2 \%(\mathrm{w} / \mathrm{v})$ agarose gel, in $1 \mathrm{X}$ Tris, borate, and ethylenediaminetetraacetic acid buffer at $110 \mathrm{~V}$ for $1.5 \mathrm{~h}$ and stained with ethidium bromide $(0.5 \mu \mathrm{g} / \mathrm{mL})$. Gels with amplification fragments were visualized and photographed in ultraviolet light by a Bio-Rad Gel Documentation System (Bio-Rad Laboratories, UK). DL2000 ladder (TaKaRa Biotechnology, China) was used as the DNA molecular weight marker.

\section{RESULTS AND DISCUSSION}

\section{Primer screening}

Through preliminary screening, 20 of 53 primers were selected that amplified visible bands. Finally, $14 \mathrm{cpSSR}$ primers that produced clear, reproducible, and polymorphic bands were selected with the proper annealing temperatures (Table 2; Figure 1). Amplifications of primers 9 and 10 were illustrated in Figure 1.

The annealing temperature is an important factor affecting PCR specificity; its role is to allow the primer and template to bind. Low annealing temperatures can ensure the stability of the combination of the primer and template (Powell et al., 1995), but when the annealing temperature is too low, the primer and the template can be mismatched, and non-specific bands can be generated. However, if the annealing temperature is too high, the binding of primer and template is inhibited, and the PCR products do not appear. Therefore, the optimal annealing temperature test is necessary when screening primers. 
Table 1. Optimization of the cpSSR-PCR reaction parameters for three species of rhubarb.

\begin{tabular}{|c|c|c|c|c|c|c|}
\hline & $\begin{array}{c}\mathrm{Mg}^{2+} \\
\text { concentration } \\
(\mathrm{mM})\end{array}$ & $\begin{array}{c}\text { Taq DNA } \\
\text { polymerase } \\
\text { (Units) }\end{array}$ & $\begin{array}{c}\text { dNTPs } \\
\text { concentration } \\
(\mathrm{mM})\end{array}$ & $\begin{array}{c}\text { Primer } \\
\text { concentration } \\
(\mu \mathrm{M})\end{array}$ & $\begin{array}{c}\text { DNA template } \\
\text { concentration } \\
\text { (ng) }\end{array}$ & $\begin{array}{c}\text { Annealing } \\
\text { temperature } \\
\left({ }^{\circ} \mathrm{C}\right)\end{array}$ \\
\hline & 0.5 & 0.25 & 0.04 & 0.10 & 5 & 56 \\
\hline & 0.7 & 0.50 & 0.06 & 0.20 & 10 & 57 \\
\hline & 1.0 & 1.00 & 0.08 & 0.30 & 15 & 58 \\
\hline & 1.5 & 1.50 & 0.10 & 0.40 & 20 & 59 \\
\hline & 2.0 & 2.00 & 0.20 & 0.50 & 30 & 60 \\
\hline & 2.5 & 2.50 & 0.25 & 0.60 & 40 & 61 \\
\hline & 3.0 & - & 0.30 & 0.80 & 50 & - \\
\hline & - & - & 0.40 & - & 100 & - \\
\hline Optimum conditions & 2.0 & 1.0 & 0.10 & 0.80 & 20 & $56-58$ \\
\hline
\end{tabular}

Table 2. Fourteen cpSSR primers selected.

\begin{tabular}{|c|c|c|c|c|}
\hline Primer code & Gene names & Primer sequences $\left(5^{\prime}-3^{\prime}\right)$ & SSR motif & Optimal annealing temperature $\left({ }^{\circ} \mathrm{C}\right)$ \\
\hline \multirow[t]{2}{*}{1} & Rpl2-Rpl23 & F: GCT TAT GAC CTC CCC CTC TAT GC & & \\
\hline & & R: TGC ATT ACA GAC GTA TGA TCA TTA & $(\mathrm{T})_{9}$ & 56 \\
\hline \multirow[t]{2}{*}{2} & TrnL & F: TAC GAG ATC ACC CCT TTC ATT C & & \\
\hline & & R: CCT GGC CCA ACC CTA GAC A & $(\mathrm{T})_{7} \mathrm{C}(\mathrm{T})_{2}$ & 57 \\
\hline \multirow[t]{2}{*}{3} & Rrn5-TrnR & F: CAC ACC AAT CCA TCC CGA ACT & & \\
\hline & & R: GGT GCG TTC CGR GGT GTG A & $(\mathrm{A})_{13}$ & 58 \\
\hline \multirow[t]{2}{*}{4} & Ycf5 & F: TCG TTG GAT TTC TTC DGG ACA TTT & & \\
\hline & Ycf5 & $\begin{array}{l}\text { R: CCC AAT ATC ATC ATA CTT ACR TGC } \\
\text { F: CTA TGC AGC TCT TTT ATG YGG ATC }\end{array}$ & $(\mathrm{A})_{8}$ & 56 \\
\hline 5 & & R: TCC ARG TAA TAA ATG CCC AAG TT & $(\mathrm{T})_{8}$ & 56 \\
\hline \multirow[t]{2}{*}{6} & TrnR-Rrn5 & F: CCA CCC CGT CTC SAC TGG ATC T & & \\
\hline & & R: AAA AAT AGC TCG ACG CCA GGA T & $(\mathrm{T})_{13}$ & 57 \\
\hline 7 & TrnL-16SrRNA & $\begin{array}{l}\text { F: CCG ACC TAG GAT AAT AAG CYC ATG } \\
\text { R: GGA AGG TGC GGC TGG ATC }\end{array}$ & & 56 \\
\hline \multirow[t]{2}{*}{8} & Rp12-TrnH & F: AYG GRG GTG GTG AAG GGA G & $(1)_{8}$ & 50 \\
\hline & & R: TCA ATT CCC GTC GTT CGC C & $(\mathrm{A})_{14}$ & 56 \\
\hline \multirow[t]{2}{*}{9} & RpoB & F: CGA CAA TCC TTC CTA ATT CAC & & \\
\hline & PsbC-TrnS & $\begin{array}{l}\text { R: AGA AAA GMA AGG ATA TGG GCT C } \\
\text { F: CGG GAA GGG CTC GKG CAG }\end{array}$ & $(\mathrm{T})_{8}$ & 56 \\
\hline 10 & PSDC-IIns & R: GTT CGA ATC CCT CTC TCT CCT TTT & $(\mathrm{T})_{11}$ & 58 \\
\hline \multirow[t]{2}{*}{11} & $\operatorname{TrnK}$ & F: TCA AAT GAT ACA TAG TGC GAT ACA & & \\
\hline & & R: AAT AAA GGA TTT CTA ACC ATC TT & $(\mathrm{T})_{10}$ & 56 \\
\hline \multirow[t]{2}{*}{12} & Rps2-RpoC2 & F: TCT GAT AAA AAA CGA GCA GTT CT & & \\
\hline & & R: GAG AAG GTT CCA TCG GAA CAA & $(\mathrm{T})_{10}$ & 56 \\
\hline \multirow[t]{2}{*}{13} & Ycf3 & F: GAG GAT ACA CGA CAG ARG GAR TTG & & \\
\hline & & R: CCT ATT ACA GAG ATG GTG YGA TTT & $(\mathrm{A})_{13}$ & 57 \\
\hline \multirow[t]{2}{*}{14} & Rps19-Rpl2 & F: GGG TAT AAT GGT AGA TGC CC & & \\
\hline & & R: GCC GTA GTA AAT AGG AGA GAA A & $(\mathrm{T})_{14}$ & 56 \\
\hline
\end{tabular}

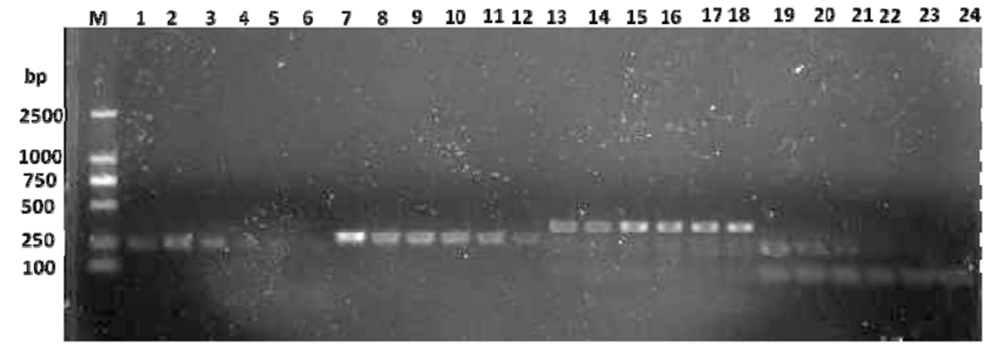

Figure 1. Amplification result of cpSSR by primers $1,3,9$, and 10 by using different annealing temperature. Lane $M=$ marker; lanes $1-6=$ Primer $1,56-61{ }^{\circ} \mathrm{C}$; lanes $7-12=$ Primer 3, 56- $61^{\circ} \mathrm{C}$; lanes $13-18=$ Primer 9, 56- $61{ }^{\circ} \mathrm{C}$; lanes $19-24$ $=$ Primer $10,56-61^{\circ} \mathrm{C}$. 


\section{Optimization of the $\mathrm{Mg}^{2+}$ concentration}

It has been reported that the PCR yield rate was subject to the $\mathrm{Mg}^{2+}$ concentration. When the $\mathrm{Mg}^{2+}$ concentration was below $0.5 \mathrm{mM}$ or above $2.0 \mathrm{mM}$, there were no amplification products. The largest yield was obtained when the concentration was $2.0 \mathrm{mM}$ (Figure 2).

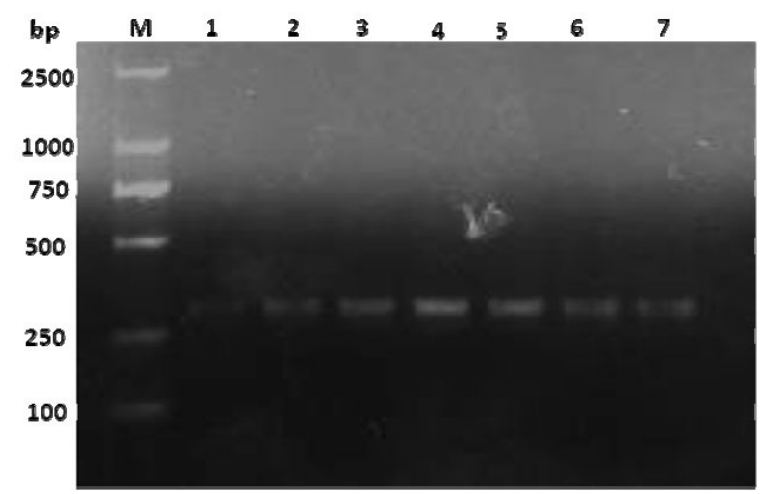

Figure 2. Amplification result of cpSSR with different concentration of $\mathrm{MgCl}_{2}$ by primer 2. Lane $M=$ marker; lanes $1-7=0.5,1.0,1.5,2.0,2.25,2.5,3.0 \mathrm{mM}$.

$\mathrm{Mg}^{2+}$ is the activator of Taq DNA polymerase, and its concentration has an important effect on the enzyme activity, primer specificity, and PCR amplification efficiency. If the $\mathrm{Mg}^{2+}$ concentration is too high, non-specific amplification products would be generated easily, and background interference is strengthened. Meanwhile, an $\mathrm{Mg}^{2+}$ concentration that is too low would reduce the amplification products, possibly resulting in no amplified products (Zhen et al., 2007).

\section{Optimization of Taq DNA polymerase}

PCR products significantly increased when the amount of Taq DNA polymerase reached 1.0 U. In order to reduce the cost of experiments, $1.0 \mathrm{U}$ Taq DNA polymerase was suggested as the optimum amount (Figure 3).

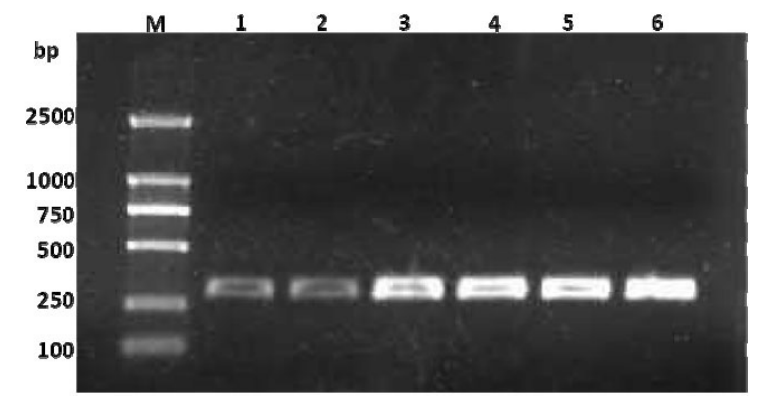

Figure 3. Amplification result of cpSSR with different amount of Taq DNA polymerase by primer 4. Lane $M=$ marker; lanes $1-6=0.25,0.50,1.00,1.50,2.00,2.50 \mathrm{U}$. 
Taq DNA polymerase is also an important factor that affects PCR amplification. Excessive Taq DNA polymerase increases not only the cost of experiments but also the number of non-specific amplification products. Of course, too little Taq DNA polymerase reduces the amount of PCR products (Zhen et al., 2007).

\section{Optimization of the primer concentration}

When the primer concentration increased, the yield of PCR products was also enhanced. As illustrated in Figure 4, there were good amplification bands at the 0.5, 0.6, and 0.8 $\mu \mathrm{M}$ primer concentrations, and the most PCR product was harvested at $0.8 \mu \mathrm{M}$. Thus, we can select different primer concentrations according to the experimental purposes. For example, we can use the $0.5 \mu \mathrm{M}$ primer concentration in the detection test in order to reduce the cost, while $0.8 \mu \mathrm{M}$ can be used to obtain more PCR products.

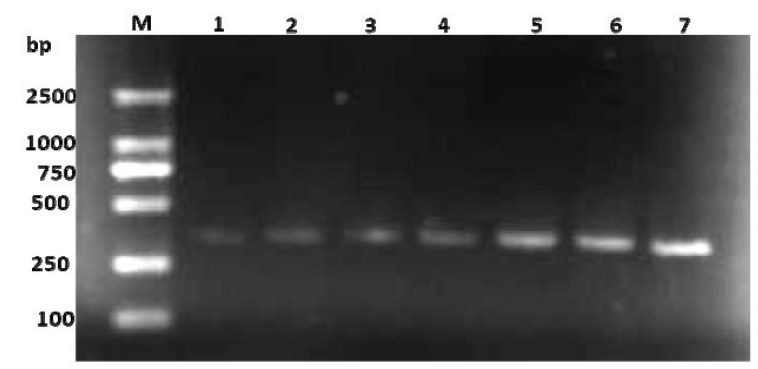

Figure 4. Amplification result of cpSSR with different concentration of primer by primer 2. Lane $M=$ marker; lanes $1-7=0.10,0.20,0.30,0.40,0.50,0.60,0.80 \mu \mathrm{M}$.

The binding capacity of the primer with the template is a main factor that affects the amount and the stability of amplification products. Primer concentrations that are too high cause non-specific amplification, and primer concentrations that are too low result in an insufficient amount of PCR product, which can affect the detection of PCR products.

\section{Optimization of the dNTP concentration}

As revealed by Figure 5, the PCR yield reached its maximum when the dNTP concentration was $0.1,0.2$, and $0.25 \mathrm{mM}$. If the concentration was higher than $0.25 \mathrm{mM}$, the PCR yield decreased. In order to reduce the experiment cost, the optimal dNTP concentration was $0.1 \mathrm{mM}$.

dNTPs are the raw materials of the amplified target sequence. If the dNTP concentration was higher than $0.25 \mathrm{mM}$, the activity of Taq DNA polymerase was inhibited (Zheng and $\mathrm{Lu}, 2003)$. When the dNTP concentration was too low, the PCR ended prematurely. Therefore, the optimal concentration should be selected.

\section{Optimization of DNA template}

Figure 6 showed that the PCR yield was subject to the DNA template concentration. In this experiment, PCR products increased as the DNA template concentrations increased, 
but there was not a strictly positive relationship between them. The PCR yield rate did not increase when the DNA template amount was $20 \mathrm{ng}$. Therefore, we recommended that $20 \mathrm{ng}$ DNA template is suitable and economic.

The quality of DNA template is very important for PCR amplification. Protein or residual impurities in the template inhibit the amplification.

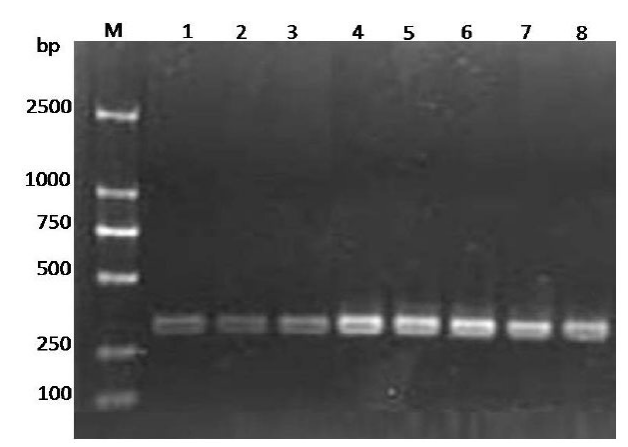

Figure 5. Amplification result of cpSSR with different concentration of dNTP by primer 6. Lane $M=$ marker; lanes $1-10=0.04,0.06,0.08,0.10,0.20,0.25,0.30,0.40 \mathrm{mM}$.

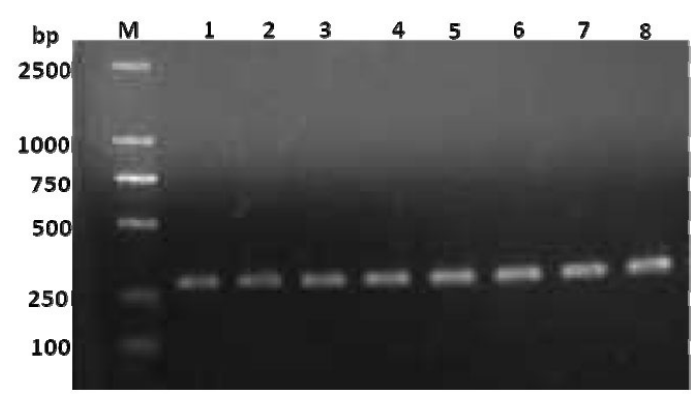

Figure 6. Amplification result of cpSSR with different concentration of template DNA by primer 8. Lane $M=$ marker; lanes 1-8 =5, 10, 15, 20, 30, 40, 50, 100ng.

\section{CONCLUSION}

In this study, the optimal cpSSRs-PCR conditions were obtained for a total reaction volume of $25 \mu \mathrm{L}$ : $20 \mathrm{ng}$ DNA template, $0.8 \mu \mathrm{M}$ primers, $1 \mathrm{U}$ Taq DNA polymerase, $2.0 \mathrm{mM}$ $\mathrm{Mg}^{2+}$, and $0.1 \mathrm{mM}$ dNTPs. Additionally, the best annealing temperature ranged from 56 to $58^{\circ} \mathrm{C}$ for each primer. According to our optimal conditions, 14 of 53 primers were chosen for their clarity and repetition in three species.

\section{ACKNOWLEDGMENTS}

Research supported by the National Natural Science Foundation of China (\#81001602). 


\section{REFERENCES}

Bao BJ and Grabovskaya-Borodina AE (2003). Rheum. In: Flora of China, Beijing and Missouri Botanical Garden (Li AR and Bao BJ, eds.). Science Press, St. Louis, 341-350.

Chen K, Peng YH, Wang YH, Korpelainen H, et al. (2007). Genetic relationships among poplar species in section Tacamahaca (Populus L.) from western Sichuan, China. Plant Sci. 172: 196-203.

Chen FJ, Wang AL, Chen KM, Wan DS, et al. (2009). Genetic diversity and population structure of the endangered and medically important Rheum tanguticum (Polygonaceae) revealed by SSR markers. Biochem. Syst. Ecol. 37: 613-621.

Cheng YJ, Guo WW and Deng XX (2003). CpSSR: A new tool to analyze chloroplast genome of Citrus somatic hybrids. Acta Bot. Sin. 45: 906-909.

Chinese Pharmacopoeia Committee (2010). Pharmacopoeia of the People's Republic of China. China Medical Science and Technology Press, Beijing.

Chung SM and Staub JE (2003). The development and evaluation of consensus chloroplast primer pairs that possess highly variable sequence regions in a diverse array of plant taxa. Theor. Appl. Genet. 107: 757-767.

Cubas P, Pardo C and Tahiri H (2005). Genetic variation and relationships among Ulex (Fabaceae) species in southern Spain and northern Morocco assessed by chloroplast microsatellite (cpSSR) markers. Am. J. Bot. 92: 2031-2043.

Doyle JJ and Doyle JL (1987). A rapid DNA isolation procedure for small quantities of fresh leaf material. Phytochem. Bull. 19: 11-15.

Gao X, Liu YP, Zhang FB and Liu Y (2008). The effects of the different extracts from Qing-zang Rheum tanguticum on the immunity function of mice. Lishizhen Med. Mat. Med. Res. 19: 1068-1069.

Hu JB, Li JW, Liang FF and Liu Y (2009). Characterization of microsatellites in complete chloroplast genome of cucumber (Cucumis sativus) and marker exploitation. Chin. J. Cell Biol. 32: 69-74.

Huang Q, Lu G, Shen HM, Chung MC, et al. (2007). Anti-cancer properties of anthraquinones from rhubarb. Med. Res. Rev. 27: 609-630.

Jakob SS, Ihlow A and Blattner FR (2007). Combined ecological niche modelling and molecular phylogeography revealed the evolutionary history of Hordeum marinum (Poaceae)-niche differentiation, loss of genetic diversity, and speciation in Mediterranean Quaternary refugia. Mol. Ecol. 16: 1713-1727.

Melotto-Passarin DM, Tambarussi EV, Dressano K, De Martin VF, et al. (2011). Characterization of chloroplast DNA microsatellites from Saccharum spp and related species. Genet. Mol. Res. 10: 2024-2033.

Powell W, Morgante M, McDevitt R, Vendramin GG, et al. (1995). Polymorphic simple sequence repeat regions in chloroplast genomes: applications to the population genetics of pines. Proc. Natl. Acad. Sci. U. S. A. 92: 7759-7763.

Provan J, Powell W and Hollingsworth PM (2001). Chloroplast microsatellites: new tools for studies in plant ecology and evolution. Trends Ecol. Evol. 16: 142-147.

Sebastiani F, Carnevale S and Vendramin GG (2004). A new set of mono- and dinucleotide chloroplast microsatellites in Fagaceae. Mol. Ecol. Notes 4: 259-261.

Siragusa M and Carimi F (2009). Development of specific primers for cpSSR analysis in caper, olive and grapevine using consensus chloroplast primer pairs. Sci. Hortic. 120: 14-21.

Su YF, Zheng X and Zheng JH (1998). The knowledge on rhubarb in the West. J. Beijing Med. Univ. 30: 54-55.

Vendramin GG, Lelli L, Rossi P and Morgante M (1996). A set of primers for the amplification of 20 chloroplast microsatellites in Pinaceae. Mol. Ecol. 5: 595-598.

Wang XM, Hou XQ, Zhang YQ and Li Y (2010). Distribution pattern of genuine species of rhubarb as traditional Chinese medicine. J. Med. Plants Res. 4: 1865-1876.

Wang X, Yang R, Feng S, Hou X, et al. (2012a). Genetic variation in Rheum palmatum and Rheum tanguticum (Polygonaceae), two medicinally and endemic species in China using ISSR markers. PLoS One 7: e51667.

Wang XM, Hou XQ, Zhang YQ, Yang R, et al. (2012b). Genetic diversity of the endemic and medicinally important Plant Rheum officinale as revealed by Inter-Simpe Sequence Repeat (ISSR) markers. Int. J. Mol. Sci. 13: 3900-3915.

Weising K and Gardner RC (1999). A set of conserved PCR primers for the analysis of simple sequence repeat polymorphisms in chloroplast genomes of dicotyledonous angiosperms. Genome 42: 9-19.

Zhen Z, Cao QQ, Yang K and Shen YY (2007). Establishment of cpSSR marker technology and optimization of its reaction system in genus Castanea. J. Fruit Sci. 24: 557-560.

Zheng JS and Lu B (2003). PCR Technique and its practical methods. Mol. Plant Breed. 1: 181-394. 